\title{
Transformation Products of the Urea Herbicide Dymron in Soils
}

\author{
Masaaki UCHIYAMA \\ Department of Plant Protection, Tokyo University of Agriculture and Technology, \\ Saiwai-cho, Fuchu 183, Japan
}

(Received November 22, 1983)

\begin{abstract}
Soils of three different types were treated with a relatively high dosage level (30 ppm) of [carbonyl-14 C]labeled dymron, 1-( $\alpha, \alpha$-dimethylbenzyl)-3-( $p$-tolyl)urea and were incubated at $30^{\circ} \mathrm{C}$ under upland and flooded conditions. The evolution of ${ }^{14} \mathrm{CO}_{2}$ from ${ }^{14} \mathrm{C}$-dymron was less than $1 \%$ of the initial radioactivity during 6 months of incubation in all cases. Evidences showed that soil microbes play an important role for the degradation of dymron. The major transformation products identified were cumylurea, $p$-tolylurea, $4^{\prime}$-hydroxymethyl derivative (compound IV) and $4^{\prime}$-carboxy derivative (compound $\mathbf{V}$ ). The formation of cumylurea was the main transformation pathway of dymron in the soils under upland and flooded conditions.
\end{abstract}

\section{INTRODUCTION}

Dymron, ${ }^{*}$ 1-( $\alpha, \alpha$-dimethylbenzyl)-3-( $p$-tolyl) urea (I) is an urea herbicide which controls effectively many cyperaceous weeds such as slender spikerush, umbrellaplant and bulrush in paddy fields and purple nutsedge on uplands, while it is ineffective against most broadleaved weeds. ${ }^{1,2)}$ Field trials showed marked tolerance of many useful crops. ${ }^{3,4)}$ This herbicide has been applied as pre-emergence herbicide in Japan for controlling bulrush such as Scirpus juncoides hotarui (Ohwi) and slender spikerush Eleocharis acicularis L.).

Its potential use on food crops necessiate studies on the metabolism in both plants and soils. Some observations have been reported with respect to the uptake, translocation and metabolism by several plants in connection with the selectivity of dymron among tolerant and susceptible species. ${ }^{5)}$ This paper describes the isolation and identification of the transformation products in soils under upland and

* Developed by Showa Denko Chemical Co., Ltd. In the previous paper, referred to $\mathrm{K}-223$. flooded conditions.

\section{MATERIALS AND METHODS}

\section{Chemicals}

\section{$1.1{ }^{14} C$-Dymron}

A sample with a specific activity of 3.59 $\mathrm{mCi} / \mathrm{mmol}$ labeled in the carbonyl carbon atom was synthesized according to the reaction sequence shown in Fig. 1. Radiochemical purity was estimated to be greater than $99 \%$ by thin-layer chromatography and autoradiography.

\subsection{Standard compounds}

The following compounds were synthesized for the purpose of comparison in thin-layer chromatographic studies. The chemical structures, identified by number, are shown in Table 1.

1 - ( $\alpha, \alpha$-Dimethylbenzyl) - 3 - (2' - hydroxy -4 'methylphenyl)urea (II), 1-( $\alpha, \alpha$-dimethylbenzyl)-3-(3'-hydroxy-4'-methylphenyl)urea (III), 1 - $(\alpha, \alpha$-dimethylbenzyl) - 3 - (4'-hydroxymethylphenyl)urea (IV), 1-( $\alpha, \alpha$-dimethylbenzyl)-3-(4'carboxyphenyl)urea (V), 1-(4-hydroxy- $\alpha, \alpha$-dimethylbenzyl)-3-( $p$-tolyl)urea (VI), $1-(\alpha, \alpha$-dimethylbenzyl) - 3 - (4' - methoxymethylphenyl)- 

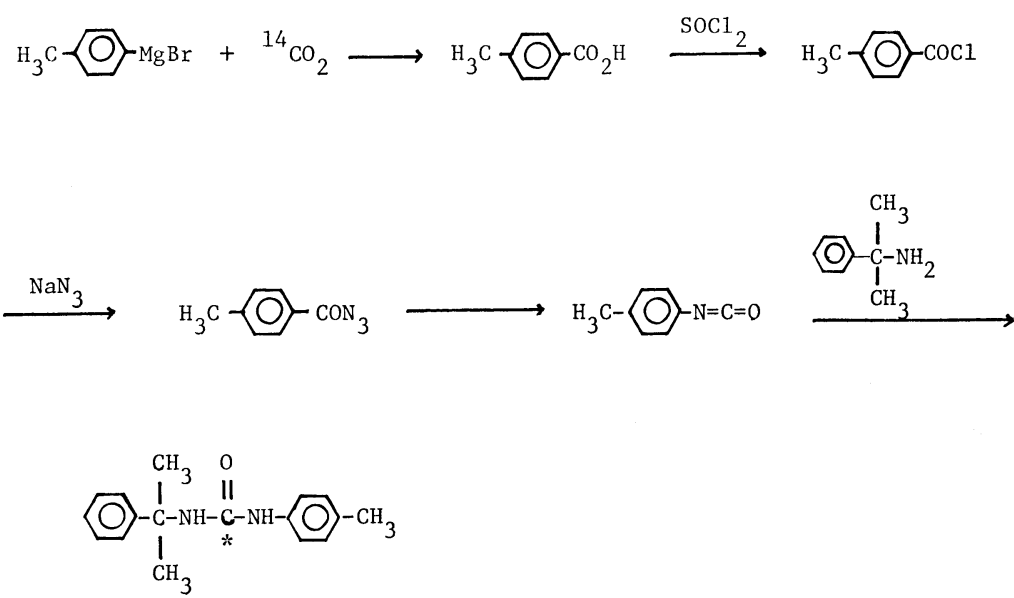

( I )

Fig. 1 Synthetic reaction sequence of [carbonyl-14C]labeled dymron.

* The labeled carbon.

Table 1 Structure and major fragment ions of synthetic reference compounds.

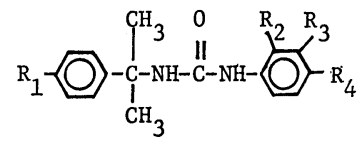

\begin{tabular}{|c|c|c|c|c|c|c|}
\hline Compound & $\mathrm{R}_{1}$ & $\mathrm{R}_{2}$ & $\mathrm{R}_{3}$ & $\mathrm{R}_{4}$ & {$\left[\mathrm{M}^{+}\right]$} & Major ions (Relative intensity) \\
\hline II & $\mathrm{H}$ & $\mathrm{OH}$ & $\mathrm{H}$ & $\mathrm{CH}_{3}$ & 284 & $\begin{array}{l}149(64), 146(66), 123(36), 120(100), 91(16) \text {, } \\
77(44)\end{array}$ \\
\hline III & $\mathrm{H}$ & $\mathrm{H}$ & $\mathrm{OH}$ & $\mathrm{CH}_{3}$ & 285 & $\begin{array}{l}149(51), 156(82), 123(73), 120(100), 91(23), \\
77(50)\end{array}$ \\
\hline IV & $\mathrm{H}$ & $\mathrm{H}$ & $\mathrm{H}$ & $\mathrm{CH}_{2} \mathrm{OH}$ & 284 & $\begin{array}{l}149(40), 146(91), 123(85), 120(100), 106(40), \\
91(37), 77(83)\end{array}$ \\
\hline $\mathbf{V}$ & $\mathrm{H}$ & $\mathrm{H}$ & $\mathrm{H}$ & $\mathrm{CO}_{2} \mathrm{H}$ & 298 & $\begin{array}{l}163(50), 146(72), 137(21), 120(100), 91(13), \\
77(20)\end{array}$ \\
\hline VI & $\mathrm{OH}$ & $\mathrm{H}$ & $\mathrm{H}$ & $\mathrm{CH}_{3}$ & 284 & $\begin{array}{l}150(11), 134(71), 133(48), 119(51), 107(88), \\
106(100), 91(87), 77(38)\end{array}$ \\
\hline VII & $\mathrm{H}$ & $\mathrm{H}$ & $\mathrm{H}$ & $\mathrm{CH}_{2} \mathrm{OCH}_{3}$ & 298 & $\begin{array}{l}163(15), 146(68), 137(59), 132(31), 120(59), \\
106(100), 91(31)\end{array}$ \\
\hline VIII & $\mathrm{H}$ & $\mathrm{H}$ & $\mathrm{H}$ & $\mathrm{CO}_{2} \mathrm{CH}_{3}$ & 312 & $\begin{array}{l}177(48), 161(19), 151(90), 146(100), 120(97), \\
91(45), 77(70)\end{array}$ \\
\hline IX & & & & & 178 & $\begin{array}{l}163(50), 120(100), 119(14), 91(32), 77(42), \\
42(100)\end{array}$ \\
\hline $\mathbf{x}$ & & & & & 150 & $107(100), 106(100), 77(23)$ \\
\hline
\end{tabular}

urea (VII), 1-( $\alpha, \alpha$-dimethylbenzyl)-3-(4'-methoxycarbonylphenyl)urea (VIII), cumylurea (IX) and $p$-tolylurea $(\mathbf{X})$. The mass and infrared spectra confirmed the identities of these compounds. 
Table 2 Properties of soils used in dymron degradation tests.

\begin{tabular}{lcccccccc}
\hline Soil & $\begin{array}{c}\text { Sand } \\
(\%)\end{array}$ & $\begin{array}{c}\text { Silt } \\
(\%)\end{array}$ & $\begin{array}{c}\text { Clay } \\
(\%)\end{array}$ & $\begin{array}{c}\mathrm{T}-\mathrm{C} \\
(\%)\end{array}$ & $\begin{array}{c}\mathrm{T}-\mathrm{N} \\
(\%)\end{array}$ & $\mathrm{C} / \mathrm{N}$ & $\mathrm{pH}\left(\mathrm{H}_{2} \mathrm{O}\right)$ & $\begin{array}{c}\mathrm{CEC} \\
(\mathrm{meq} / 100 \mathrm{~g})\end{array}$ \\
\hline A (Loam) & 63.3 & 36.7 & - & 4.9 & 0.41 & 12 & 5.9 & 31 \\
B (Heavy clay) & 15.7 & 37.1 & 47.2 & 0.9 & 0.12 & 8 & 4.7 & 21 \\
C (Sand) & 90.4 & 9.6 & - & 1.0 & 0.07 & 14 & 5.9 & 9 \\
\hline
\end{tabular}

\section{Soil Treatment}

\subsection{Soil samples}

Three soils were collected from the cultivated soil of paddy fields in Chiba. The soil properties are shown in Table 2. The soils were half air-dried, crushed finely, passed through a $2 \mathrm{~mm}$ sieve and stored at $5^{\circ} \mathrm{C}$ until starting the experiments.

\subsection{Treatment under upland conditions}

Experiments were conducted to determine the rate of dymron degradation in the soils by monitoring ${ }^{14} \mathrm{CO}_{2}$ evolution. ${ }^{14} \mathrm{C}$-Dymron was dissolved in acetone and $0.1 \mathrm{ml}$ of the solution was added to duplicate samples of each soil ( $50 \mathrm{~g}$, dry weight) at the rate of $30 \mathrm{ppm}$ on the dry weight basis. The soil was throughly mixed and placed in an incubation vessel $(7 \times$ $30 \mathrm{~cm}$ cylindrical vessel). Soil moisture content was adjusted to $65-70 \%$ of the field capacity and incubated at $30^{\circ} \mathrm{C}$ in the dark. Ten $\mathrm{ml}$ of $1 \mathrm{~N}-\mathrm{NaOH}$ solution was used as the ${ }^{14} \mathrm{CO}_{2}$ trapping solution. The solution was replaced every ten days for the radioactivity determination. At the same time, the vessel was allowed to open for aeration. In another experiment each soil treated with ${ }^{14} \mathrm{C}$-dymron (30 ppm) in the same manner was placed in an Erlenmeyer flask $(200 \mathrm{ml})$, covered with aluminium foil and incubated at $30^{\circ} \mathrm{C}$. Water was added as necessary to maintain the moisture level.

\subsection{Treatment under flooded conditions}

Each soil sample $(50 \mathrm{~g})$ was placed in a 300 $\mathrm{ml}$ bottle with an inner diameter $5 \mathrm{~cm}$, and submerged $1 \mathrm{~cm}$ deep in water. The bottle opening was capped tightly. The soil was preincubated in the dark at $30^{\circ} \mathrm{C}$ for 2 weeks. Then, ${ }^{14} \mathrm{C}$-dymron (30 ppm) in acetone was applied on the water surface of the soil. The soil was mixed well by shaking gently and incubated at $30^{\circ} \mathrm{C}$ in the dark.

\subsection{Sterilized soil treatment}

To determine the ability of soil microorganisms to degradate the herbicide, experiments using the autoclaved soil samples were conducted. Each soil $(50 \mathrm{~g})$ was placed in an incubation flask and sterilized in an autoclave $\left(120^{\circ} \mathrm{C}, 30 \mathrm{~min}\right)$, then treated with ${ }^{14} \mathrm{C}$-dymron (30 ppm). After adjustment of the moisture level with sterilized water, the flasks were kept at $30^{\circ} \mathrm{C}$.

\section{Extraction Procedures}

\subsection{Upland soils}

The whole soil sample in each flask was extracted twice with $150 \mathrm{ml}$ of acetone, then once with $100 \mathrm{ml}$ of acetone-chloroform (1:1 $\mathrm{v} / \mathrm{v}$ ) by shaking for $30 \mathrm{~min}$, and filtered through a layer of celite on No. 3 glass filter. The filtrates were combined and concentrated under reduced pressure. The aqueous solution remaining was extracted with chloroform. The chloroform phase was concentrated and the residue was dissolved in a known volume of methanol.

\subsection{Flooded soils}

The water layer separated from the soil sample by centrifugation was extracted with two $100 \mathrm{ml}$ portions of ether. The soil was further extracted with acetone and acetonechloroform mixture as described above. The combined extracts were concentrated and made up to a known volume with methanol.

\section{Thin-layer Chromatography, Autoradio- graphy and Radioactivity Measurement}

Pre-coated silica gel plate (Merck, $60 \mathrm{~F}_{254}$, $0.25 \mathrm{~mm}$ thick) was used for thin-layer chromatography (TLC) and was developed with the solvent systems shown in Table 3. Radioactive compounds on the plate were detected by autoradiography with X-ray film (Fuji 
medical no-screen X-ray film) exposed for 7 10 days at cold room. Each radioactive spot was scraped off from the plate and the gel was eluted with chloroform-methanol $(1: 1)$. Aliquots of the desorbed components were subjected to liquid scintillation counting and the remainders were further subjected to TLC with different solvent systems for comparison of $R f$ values of the radioactive compounds with those of the unlabeled standards. The radioactivity was determined by a liquid scintillation spectrometer (Packerd Model 3320) using a dioxane-based scintillation solution $(15 \mathrm{ml})$. One $\mathrm{ml}$ of the ${ }^{14} \mathrm{CO}_{2}$ trapping solution was added to $15 \mathrm{ml}$ of NT scintillation solution $^{6)}$ and the radioactivity was measured.

\section{Mass Spectrometric Analysis}

Mass spectra were aquired with a Shimadzu LKB-9000 mass spectrometer under the following conditions: samples were introduced by direct probe, ion temperature $270^{\circ} \mathrm{C}$, ionizing energy $70 \mathrm{eV}$. A chloroform solution of each radioactive component desorbed from TLC plates was passed through a short column of silica gel (Mallinckrodt silisic acid, 100 mesh), then eluted with chloroform-methanol $(1: 1)$. The eluent was reduced in volume and transferred to a mass spectrometer sample probe.
High resolution mass spectral data were obtained using a high resolution mass spectrometer (Hitachi Model RMU-7 MG) with associated data system (Hitachi 002-Datalyser) at an ionization potential of $70 \mathrm{eV}$.

\section{RESULTS AND DISCUSSION}

\section{TLC and MS Data of Dymron and Its} Related Compounds

The $R f$ values of some of the authentic compounds (the potential transformation products) and ${ }^{14} \mathrm{C}$-labeled dymron metabolites are summarized in Table 3. The high resolution mass spectra of dymron were obtained and the major breakdown pathways were deduced therefrom (Table 4 and Fig. 2). Table 1 also shows the $\mathrm{m} / \mathrm{z}$ values and their relative intensities of several standard compounds. The major fragmentation pathways of these $1-(\alpha$, $\alpha$-dimethylbenzyl)-3-arylurea derivatives were virtually similar to those of $N$-phenylurea derivatives reported by earlier workers. $^{7,8)}$ However, several characteristic features were observed: Loss of methyl from the intermediate ions (Eqs. 2 and 5 in Fig. 2) gave diagnostically useful ions. Thus, the intense peaks at $m / z 120$ and also 146 clearly indicate the presence of the intact $\alpha, \alpha$-dimethylbenzyl moiety. The intense ions at 106 and 107 are, similarly,

Table $3 R f$ values of several reference compounds and ${ }^{14} \mathrm{C}$-components.

\begin{tabular}{|c|c|c|c|c|}
\hline \multirow{2}{*}{ Compound } & \multirow{2}{*}{$\begin{array}{c}{ }^{14} \mathrm{C} \text {-component } \\
\text { (designation in text) }\end{array}$} & \multicolumn{3}{|c|}{$R f$ values \& solvent system ${ }^{a}$ ) } \\
\hline & & I & II & III \\
\hline Dymron (I) & M-11 & 0.78 & 0.65 & 0.63 \\
\hline 2'-OH-dymron (II) & & 0.70 & 0.57 & \\
\hline 3'-OH-dymron (III) & M-8 & 0.55 & 0.42 & 0.45 \\
\hline $4^{\prime}-\mathrm{CH}_{2} \mathrm{OH}$-dymron (IV) & M-6 & 0.34 & 0.21 & 0.29 \\
\hline $4^{\prime}-\mathrm{CO}_{2} \mathrm{H}$-dymron $(\mathbf{V})$ & M-5 & 0.30 & 0.13 & 0.13 \\
\hline 4-OH-dymron (VI) & & 0.51 & 0.31 & 0.36 \\
\hline Cumylurea (IX) & M-3 & 0.19 & 0.12 & 0.33 \\
\hline Tolylurea $(\mathbf{X})$ & M-4 & 0.22 & 0.15 & 0.25 \\
\hline UK & $M-1^{b)}$ & 0.0 & & \\
\hline UK & $\left.M-2^{b}\right)$ & 0.09 & & \\
\hline UK & M-7 & 0.47 & & \\
\hline UK & M-9 & 0.57 & & \\
\hline UK & M-10 & 0.65 & & \\
\hline UK & $\left.M-12^{b}\right)$ & 0.81 & & \\
\hline
\end{tabular}

a) Solvent system; I: benzene-acetone (2:1), II: toluene-hexane-acetone (1:1:1), III: chloroform-methanol $(9: 1)$, b) presumed its identity.

UK: unknown. 
Table 4 High resolution mass spectral data for dymron.

\begin{tabular}{lrll}
\hline$m / z$ measured & Intensity & Composition & $m / z$ calcd. \\
\hline 268.1587 & 4 & $\mathrm{C}_{17} \mathrm{H}_{20} \mathrm{ON}_{2}$ & 268.1577 \\
146.0588 & 10 & $\mathrm{C}_{9} \mathrm{H}_{8} \mathrm{ON}$ & 146.0606 \\
133.0564 & 6 & $\mathrm{C}_{8} \mathrm{H}_{7} \mathrm{ON}$ & 133.0528 \\
132 & 3 & & 120.0814 \\
120.0818 & 19 & $\mathrm{C}_{8} \mathrm{H}_{10} \mathrm{~N}$ & 119.0861 \\
119.0851 & 38 & $\mathrm{C}_{9} \mathrm{H}_{11}$ & 107.0735 \\
108 & 21 & & 106.0657 \\
107.0731 & 100 & $\mathrm{C}_{7} \mathrm{H}_{9} \mathrm{~N}$ & \\
106.0653 & 41 & $\mathrm{C}_{7} \mathrm{H}_{8} \mathrm{~N}$ & 91.0548 \\
104 & 6 & & \\
103 & 6 & & \\
91.0547 & 52 & $\mathrm{C}_{7} \mathrm{H}_{7}$ & \\
79 & 19 & & \\
78 & 7 & $\mathrm{C}_{6} \mathrm{H}_{5}$ & \\
77.0393 & 27 & & \\
65 & 7 & & \\
53 & 3 & & \\
42 & 27 & & \\
\hline
\end{tabular}

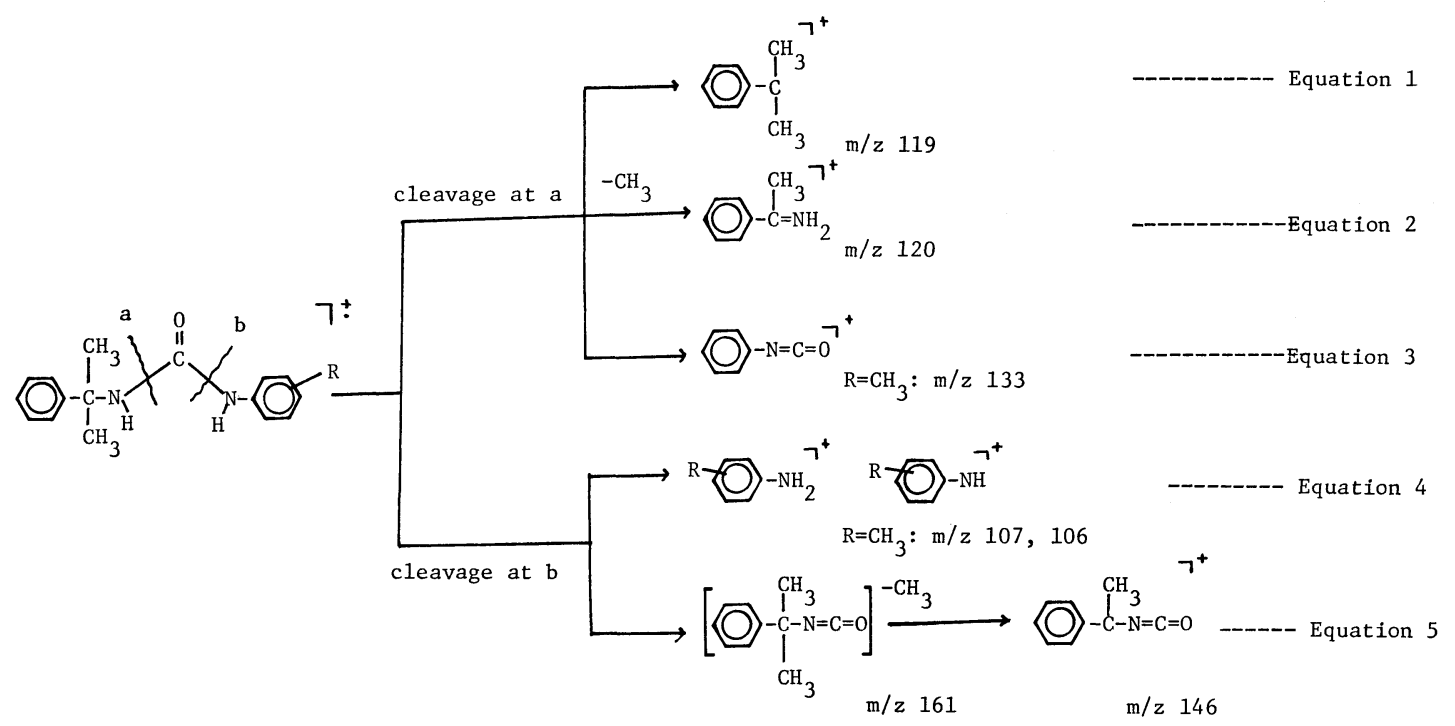

Fig. 2 Major mass fragmentation pathways of dymron and its related compounds.

indicative of the presence of the intact $p$ tolyl nucleus.

2. Examination of the Extracts by TLC Analysis

The cumulated amount of ${ }^{14} \mathrm{CO}_{2}$ evolved from the soil-incorporated dymron was, even after 6 months of incubation, less than $1 \%$ of the initially applied radioactivity in all cases. This suggests that most of ${ }^{14} \mathrm{C}$-components in the soils still retain the ureido structure. After 2 months of incubation, a large portion of the soil-incorporated radiocarbon (86-89\% in the upland soils and $76-90 \%$ in the flooded soils) was recovered by the solvent extraction, but after 6 months, the solvent extractable 


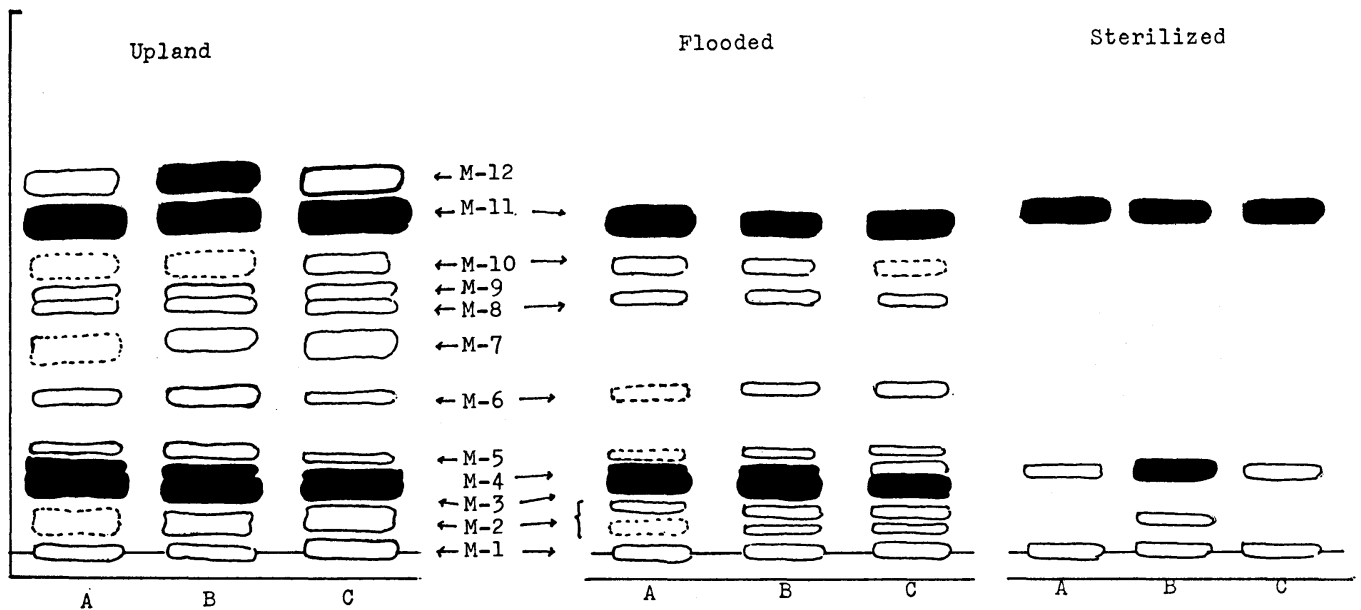

Fig. 3 Representation of TLC-autoradiograms from the extracts of soils treated with ${ }^{14} \mathrm{C}$-dymron.

Soil type: A (L), B (HC), C (S); Solvent system I.

Table 5 Relative amounts of ${ }^{14} \mathrm{C}$-components recovered from extracts of soils treated with ${ }^{14} \mathrm{C}$-dymron.

\begin{tabular}{|c|c|c|c|c|c|c|}
\hline \multirow{3}{*}{${ }^{14} \mathrm{C}$-Component } & \multicolumn{6}{|c|}{ Distribution of radioactivity $(\%)^{a)}$} \\
\hline & \multicolumn{3}{|c|}{ Upland soil } & \multicolumn{3}{|c|}{ Flooded soil } \\
\hline & A & B & $\mathrm{C}$ & A & $\mathrm{B}$ & $\mathrm{C}$ \\
\hline M-1 & 1.9 & 3.6 & 8.0 & 0.8 & 3.8 & 1.7 \\
\hline M-2 & 1.5 & 5.5 & 4.6 & 1.0 & 4.8 & 3.6 \\
\hline $\begin{array}{l}\text { M-3 } \\
\text { M-4 }\end{array}$ & 63.3 & 29.1 & 29.8 & 16.0 & 74.0 & 59.8 \\
\hline M-5 & 1.9 & 11.3 & 1.9 & 0.4 & 3.8 & 1.2 \\
\hline M-6 & 1.3 & 7.5 & 2.9 & 0.5 & 5.2 & 1.8 \\
\hline M-7 & 0.5 & 1.9 & 1.9 & - & 一 & - \\
\hline M-8 & 0.4 & 1.6 & 1.0 & 1.0 & 1.7 & 1.3 \\
\hline M-9 & 1.3 & 3.6 & 3.9 & - & - & - \\
\hline M-10 & 0.4 & 0.7 & 1.8 & 3.9 & 1.0 & 0.7 \\
\hline $\mathrm{M}-11$ & 26.4 & 16.4 & 40.2 & 76.4 & 5.7 & 29.9 \\
\hline $\mathrm{M}-12$ & 1.1 & 18.8 & 4.0 & - & - & - \\
\hline
\end{tabular}

a) Data based on quantitation of ${ }^{14} \mathrm{C}$-components separated by TLC and presented as percent of total radioactivity recovered.

radioactivity from the loam soil (Soil A) and the heavy clay soil (Soil B) under upland conditions were reduced to $42 \%$ and $32 \%$, respectively. However, $74 \%$ and $85 \%$ of ${ }^{14} \mathrm{C}$ were recovered from the same soils under flooded conditions. On the other hand, the extraction rate from the sandy soil (Soil C) was $57 \%$ under both upland and flooded conditions.

Preliminary TLC examinations showed that the major part of ${ }^{14} \mathrm{C}$ in the solvent extracts of the soils was attributable to the unchanged herbicide when it was incubated for 2 months under both upland and flooded conditions. After 6 months, however, the extracts from the soils incubated under upland and flooded conditions gave at least 12 and 8 radioactive spots, respectively, on TLC-autoradiograms (Fig. 3). Table 5 shows the relative amounts of these ${ }^{14} \mathrm{C}$-components. Any significant 
qualitative differences were hardly observed among soil types except for the anomalously less polar component, M-12 which was only detected in the extracts from the soils under upland conditions. There were, however, considerable quantitative differences in the relative amounts of the major components, M-3, M-4, M-11 and M-12 among soil types. In the same manner, the solvent extracts from the autoclaved soils incubated for up to a year were examined by TLC and the distribution of the ${ }^{14} \mathrm{C}$-components were determined. Over $90 \%$ of the radioactivity was recovered as the parent herbicide from the loam soil (Soil A) and sandy soil (Soil C), but in the case of the heavy clay soil (Soil B), only $58 \%$ was recovered from the unchanged herbicide and $37 \%$ was found in the transformation product, M-4. However, the major component, M-3 in the non-autoclaved soils was not detected in the extracts from the autoclaved soils. These results suggest that soil microbes play a significant role in the transformation of dymron in soils. Therefore, dymron persistence in soil would be greatly prolonged when conditions for microbial activity are not favorable. This may explain for the prolonged lag periods of dymron degradation in these experiments. The conversion of dymron to M-4 appears to occur partly by a non-biological mechanism.

\section{Isolation and Identification of the Major Transformation Products}

To obtain ${ }^{14} \mathrm{C}$-labeled transformation products in sufficient quantities for their identity, the extracts were combined and concentrated to subject to the preparative TLC with solvent system I. The radioactive zones were scraped by the guidance of autoradiograms and further examined after desorption from the gel. The incompletely separable components M-3 and -4 were resolved into two radioactive zones, $R f 0.33$ and 0.25 , respectively, by use of solvent system III. The relative amounts were $\mathrm{M}-3,87-90 \%$ and $\mathrm{M}-4,10-13 \%$.

The main component M-3 was identified with cumylurea (IX) based on the following evidence; It had $R f$ values identical with the authentic compound by co-TLC with solvent system I, II, and III. Mass fragments appeared at $m / z 178\left(\mathrm{M}^{+}\right), 163\left(\mathrm{M}-\mathrm{CH}_{3}\right), 120$ (base peak) corresponding $\mathrm{C}_{6} \mathrm{H}_{5} \mathrm{C}\left(\mathrm{CH}_{3}\right)=\mathrm{NH}_{2}$ and 91 indicated the diagnostic fragmentation pathways for cumylurea (Table 1 and Fig. 4).

Component M-4 was identified with $p$ tolylurea $(\mathbf{X})$ by cochromatography and mass spectral evidences compared with the authentic compound. Regardless the presence of impurities, the appearance of the necessary fragments, molecular ion at $m / z 150$ and intense peaks at 106 and 107 (base peak), confirmed this identity.

Component M-5 was identified 1-( $\alpha, \alpha$-dimethylbenzyl) - 3-(4'-carboxyphenyl) urea (V)

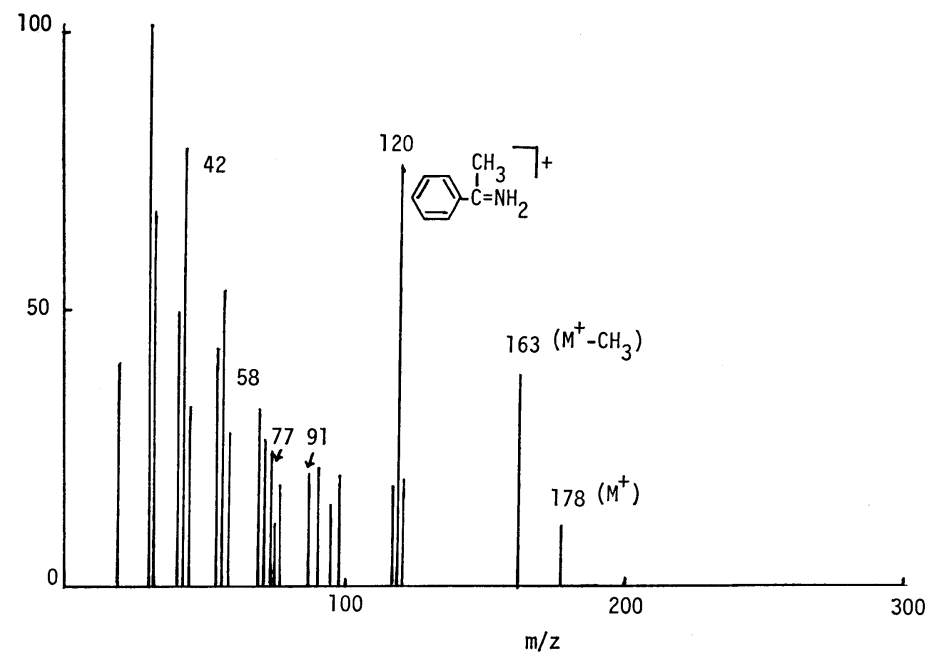

Fig. 4 Mass spectrum of the isolated component, M-3. 
based on the following evidence: it had $R f$ value identical with the authentic compound. By the esterification with diazomethane, it gave another radioactive spot coincided with $4^{\prime}-\mathrm{CO}_{2} \mathrm{CH}_{3}$-dymron (VIII). Mass spectra displayed a small, but discernible molecular ion at $m / z 298$. The presence of other fragment ions at $m / z 163,146,137$ and 120 confirmed this identity. This compound had been isolated and identified as the major urinary metabolite of dymron in rats. ${ }^{9)}$

Component M-6 was identified with $1-(\alpha, \alpha-$ dimethylbenzyl) - 3-(4'-hydroxymethylphenyl)urea (IV) based on the following evidences; It had $R f$ values identical with the authentic compound by co-TLC with solvent system I, II and III. The hydroxymethyl derivative (IV) is smoothly converted to its methyl ether (VII) in anhydrous methanol containing trace amount of $p$-toluenesulfonic acid at room temperature. This property was successfully applied for the identity of M-6. Thus, a mixture of M-6 and compound IV in anhydrous methanol with a catalytic amount of $p$-toluenesulfonic acid was allowed to stand over night at room temperature. The reaction product was subjected to TLC, then autoradiographed. Radioactive spots detected on the autoradiogram and spots visualized under ultraviolet lamp on the TLC plate were completely superimposable. Mass spectrum of M6 displayed molecular ion at $m / z 284$ and other diagnostic ions at $m / z 149,146,123,120,106$ and 91 for the compound IV.

Component M-8 was identified with 1( $\alpha, \alpha$-dimethylbenzyl)-3-(3'-hydroxy-4'-methylphenyl)urea (III) by co-TLC with solvent system I and II and by the appearance of molecular ion at $m / z 284$ and other mass fragments at $m / z 149,146,123,120$ supporting this identity.

Component M-11 was identified with the parent herbicide, dymron by co-TLC and by comparison of the mass fragmentation pattern with that of the authentic compound.

The characterization of component M-12 by means of mass spectral analysis was unsuccessful. A large amount of phthalates that had been contaminated in the soils prevented us from obtaining an unequivocal mass spectrum of this ${ }^{14} \mathrm{C}$-labeled component. Therefore, attempts were made to characterize this anomalous product by means of chemical examinations. Most of ${ }^{14} \mathrm{C}$-label was lost by treating with $1 \mathrm{~N}-\mathrm{HCl}$ for $6 \mathrm{hr}$ in a boiling water bath. Treatment with methanolic ammonia gave another radioactive spot located closely to cumylurea on TLC. Based on these observations and the comparison of the $R f$ values with those of several synthetic samples of $N$-alkyl- $\alpha, \alpha$-dimethylbenzylcarbamates, it was presumed that M-12 may partly consist of $\alpha, \alpha$-dimethylbenzylcarbamate derivative with some natural nucleophiles.

Component M-7, -9 and -10 remained unidentified. Their $R f$ values did not coincide with those of any of the reference compounds.

The polar ${ }^{14} \mathrm{C}$-components desorbed from the combined broad radioactive zones (M-1 plus $\mathrm{M}-2$ ) were dissolved in $0.1 \mathrm{~N}-\mathrm{HCl}$ and extracted with chloroform. The chloroform layer was concentrated and subjected to TLC with solvent system III and autoradiographed. The autoradiogram revealed at least 6 radioactive zones. The main two were coincided with cumylurea and 4'- $\mathrm{CO}_{2} \mathrm{H}$-dymron by co-TLC. Further, two faint zones were located closely to $p$-tolylurea and dymron cochromatographed alongside. This may suggest that dymron and its transformation products exist, in part, as some complexes with natural substances.

Based on the results described above, the transformation pathways of dymron in soils were presumed as shown in Fig. 5. The pathway shown with dashed arrow was postulated, but their identities were not fully established. Although the bracketed compounds were assumed to be formed in soils, we have no direct evidence for them. The comparative studies on dymron transformation in non-autoclaved and autoclaved soils strongly suggested that microbial breakdown is a major cause of dymron loss from soil.

Of special interest was the detection of cumylurea which was isolated and identified as a major transformation product of dymron in the soils. Undoubtedly soil microorganisms play an important role in this transformation, since cumylurea was not detected in the autoclaved soils. We presume that this specific transformation may occur via an unstable intermediate, which was most likely formed by a microbial nitrosative degradation ${ }^{10-13)}$ of 


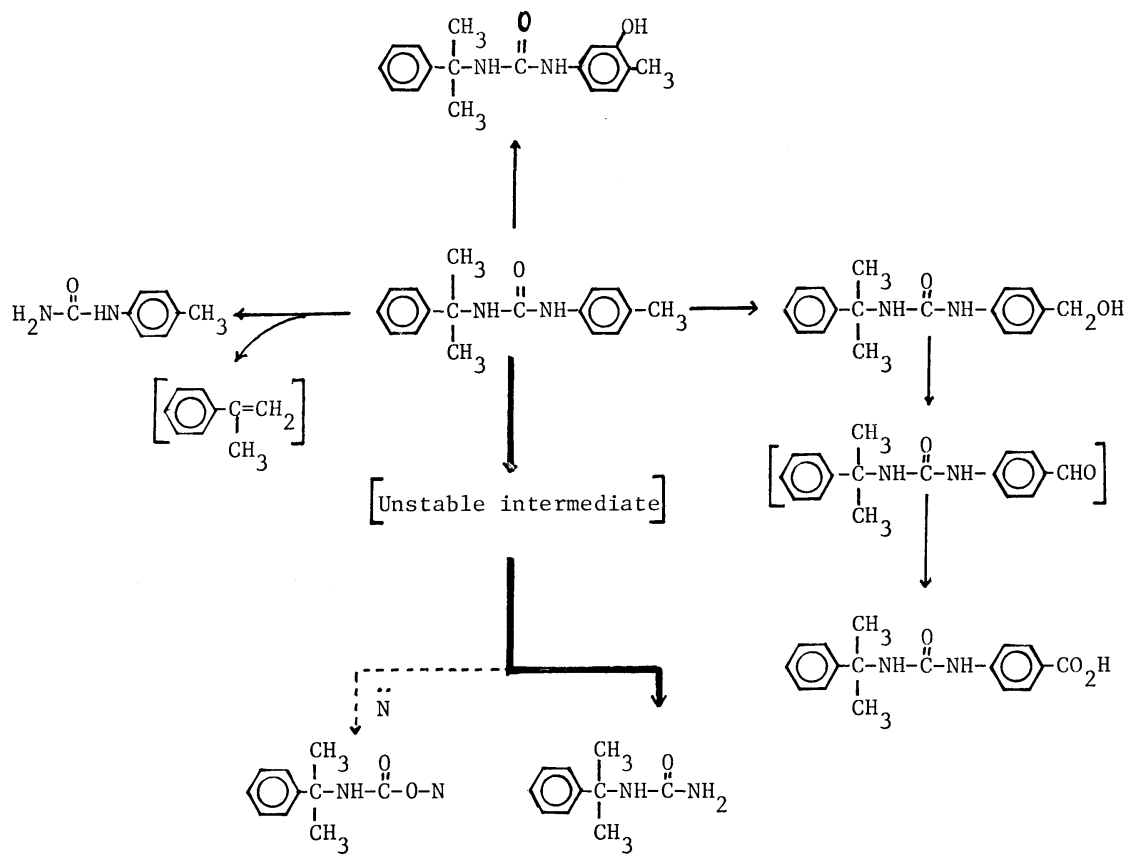

Fig. 5 Postulated transformation pathways of dymron in soils.

Solid arrows and unbracked compounds were determined experimentally. Dashed arrow and bracked compounds were postulated. $\mathrm{N}$ : Natural nucleophile.

dymron in the soils. A possible mechanism for the formation of the intermediate and the subsequent transformation giving cumylurea and M-12 will be presented elsewhere in connection with a variety of environmental concerns.

Another major transformation pathway of the soil-applied dymron was stepwise oxidation of the ring substituted methyl group to form first 4'- $\mathrm{CH}_{2} \mathrm{OH}$-dymron (M-6) and then $4^{\prime}-\mathrm{CO}_{2} \mathrm{H}$-dymron (M-5). Ring hydroxylation at the 3 -position of the tolyl ring represented a minor rout.

\section{REFERENCES}

1) T. Takematsu, H. Kubo, N. Seki, N. Sato \& Y. Omura: Proc. 5th Asian-Pacific Weed Sci. Soc. Conf., p. 121, 1976

2) T. Takematsu \& M. Konnai: Kagaku To Seibutsu 12, 379 (1974) (in Japanese)

3) T. Takematsu, M. Konnai, K. Akashiba \& N. Seki: Weed Sci. 23, 15 (1975)

4) L. I. Okafor \& S. K. DeDatta: Weed Res. 16, 1 (1976)

5) M. Uchiyama, R. Sato \& H. Kubo: Proc. 5th
Asian-Pacific Weed Sci. Soc. Conf., p. 198, 1976

6) M. Kawakami \& K. Shimura: Radioisotopes 23, 15 (1974)

7) M. A. Baldwin, A. K. Lonasiewicz, A. G. Loudon, A. Maccolland \& D. Smith: J. Chem. Soc. (B), 1968, 34

8) W. R. Benson \& J. N. Damico: J. Assoc. Off. Anal. Chem. 51, 347 (1968)

9) K. Sato, Y. Kato, S. Maki, O. Matano \& S. Goto: J. Pesticide Soc. 4, 11 (1979)

10) T. Fujita, H. Tsuji, H. Deura \& M. Nakajima: Agric. Biol. Chem. 33, 785 (1969)

11) A. Ayanabe \& M. Alexander: Appl. Microbiol. 25, 862 (1973)

12) C. T. Corke, N. J. Bunce, A. Beaumont \& R. L. Merrick: J. Agric. Food Chem. 27, 144 (1979)

13) A. M. Lammerding, N. J. Bunce, R. L. Merrick \& C. T. Corke: J. Agric. Food Chem. 30, 644 (1982)

要約

尿素系除草剤ダイムロンの土壤中での変化生 成物

内山正昭

カルボニル ${ }^{14} \mathrm{C}$ 標識ダイムロンを供試し， 3 種の土塨 
中(湛水および畑条件下)での変化生成物の分離，同定を 試みた。土塨に施用した ${ }^{14} \mathrm{C}$-ダイムロンからの ${ }^{14} \mathrm{CO}_{2}$ の 発生は僅少であり，ダイムロンのウンイド結合は長期間 安定に保持されていることが推測できた．また滅菌土塞 を使用した比較試験結果から土㙵中でのダイムロンの分 解には土壤微生物が重要な役割を果たしていることが推 察された．同定された抒もな変化生成物は, cumylurea, p-tolylurea, 1 - ( $\alpha, \alpha$-dimethylbenzyl) -3- (4'-hydroxymethylphenyl)urea おょよ゙ 1-( $\alpha, \alpha$-dimethylbenzyl)-3(4'-carboxyphenyl)urea であった. Cumylurea の生成 は, 土塨微生物の作用に起因すると想定された不安定中 間代謝物を経由すると推測されたが，土㙵中でのダイム ロン変化の主要経路であった. 